\title{
Transplant-Related Squamous Cell
}

\section{Carcinoma}

National Cancer Institute

\section{Source}

National Cancer Institute. Transplant-Related Squamous Cell Carcinoma. NCI Thesaurus.

Code C154700.

A squamous cell carcinoma that arises in a patient with a history of organ

transplantation. 